\title{
An Empirical Study of Translanguaging Practice in Interpreters' Note-Taking
}

\author{
Zhiliang Yue \\ School of Foreign Studies, Zhanjiang University of Science and Technology, Zhanjiang, China \\ Anchalee Jansem \\ Faculty of Humanities, Srinakharinwirot University, Bangkok, Thailand
}

\begin{abstract}
This paper discusses potential application of translanguaging in an interpreting course, specifically for the note-taking part. A Likert scale questionnaire is used to collect information from the participants about their relevant experiences and knowledge as well as their attitude toward application of translanguaging in future note-taking activities. Furthermore, a small-scale experiment was carried out to discover how the participants' choice of language in notes would change after gaining the awareness of potential translanguaging benefits. The findings are that most of the participants are quite agreeable to the concept of translanguaging and its application, and with a built awareness, their notes demonstrate a much more balanced usage of both their L1 and L2, although other languages in their linguistic repertoire still hardly showed any presence. This could shed light on how teachers of an interpreting course could integrate translanguaging into their pedagogy to help students fully utilize their linguistic repertoire for the optimum interpreting performance.
\end{abstract}

Index Terms — translanguaging, interpreting, note-taking

\section{INTRODUCTION}

\section{A. Statement of the Problem}

Translanguaging, a newly emerged term in recent years, remains an interesting topic for an increasing number of scholars across multiple disciplines. Originally coined by a Welsh educator Cen Williams in the 1980s (Lewis et al., 2012), the term hardly caught the academia's attention until the first decade of this century, and since then a fairly large volume of literature has been generated (Jenks \& Lee, 2020). The concept refers to "the deployment of a speaker's full linguistic repertoire without regard for watchful adherence to the socially and politically defined boundaries of named language" (Otheguy et al., 2015). In essence, translanguaging presents a revolutionary view of how bilingual/multilingual people exploit their linguistic repertoire in daily language practice, as well as what the underlying cognitive process truly looks like (Garcia, 2009).

By nature, translanguaging has a considerable potential in shedding light on understanding and teaching bilingual/multilingual students, especially in language-related courses. In this research, the authors aim to explore how this concept of translanguaging can help explain bilingual/multilingual students' note-taking behavior during interpreting, and how the teacher can guide them to take full advantage of their linguistic repertoire in note-taking for optimum interpreting performance.

\section{B. Research Questions}

Through conducting an empirical questionnaire and experiment, this study aims to answer the following three questions:

1. What experience and attitudes do students have towards language choice in their note-taking without the awareness of translanguaging?

2. How would students' choice of language in note-taking change after gaining the awareness of translanguaging?

3. How could teachers better train students in note-taking in light of the findings for the first two questions?

\section{LITERATURE REVIEW}

Various scholars' work marked the onset of the movement toward the adoption of translanguaging in educational contexts (Blackledge \& Creese, 2010; Canagarajah, 2013; Creese \& Blackledge, 2010; Garcia, 2009; Garcia \& Li, 2014; $\mathrm{Li}, 2011)$. In an effort to promote this educational policy, instructors' ideology and orientation as a key factor has been put in the spotlight for analysis. As presented in Burton and Rajendram's (2019) research report, most language instructors still seemed to lean toward one-language-only pedagogy despite their understanding of the benefits of translanguaging. On the other hand, there is a growing consensus among scholars that taking a translanguaging stance in pedagogy means viewing students' dynamic bilingualism as an advantage, rather than as a problem to be solved, which 
greatly motivates students in their study (Garcia, 2009; Garcia et al., 2016). Lewis et al. (2012) posit that translanguaging can bring four benefits to bilingual students in general, including a thorough understanding of the content, development of the weaker language, stronger home-to-school links, and expedition of the language learning process. Over the years, various scholars have explored the ways to apply the principle of translanguaging to the teaching of all four basic language skills - listening, speaking, reading and writing (Baker et al., 2019; Garcia, 2009; Kiramba, 2017; Kwon et al., 2016; Pontier et al., 2016; Turnbull, 2019).

However, translating/interpreting as an integrated skill, which entails reading/listening skill of language A (i.e., the source language) and the writing/speaking skill of language B (i.e., the target language), remains virtually untouched in the literature, as far as translanguaging application is concerned. To the best of the authors' knowledge, the only relevant work is Baynham and Lee's book "Translation and Translanguaging", in which a chapter was devoted to investigating the role of translanguaging in cyberpoetics by means of an experiment on poetry translation (Baynham \& Lee, 2019). Baynham et al. claim that the computational algorithm adopted largely mirrors how a bilingual person would utilize his/her repertoire. However, their work clearly differs from a normal classroom setting, and by considering translating only, the field of interpreting was still left out of the picture.

The origin of interpreting as a social activity dates back thousands of years, but it was not until 1919 when it finally became recognized as a real profession, and decades later, a real discipline (Xiao, 2002). Of all the aspects in interpreting, note-taking is arguably the most mysterious and debate-provoking one. Some scholars recommend taking notes in the target language (TL), on the grounds that it forces the interpreters to get rid of the original form while extracting the meaning of the speech (Mikkelson, 1983; Seleskovitch, 1975; Seleskovitch \& Lederer, 1989; Rozan, 2002). Others hold the opposite view and contend that notes should be taken in the source language (SL) so as to eliminate the burden of language conversion in the listening phase, during which period the interpreters' attention should be devoted to hearing and processing the information as much as possible (Ilg, 1988; Alexieva, 1993; Gile, 1995). Furthermore, others break away from this SL-or-TL logic and examine the matter from the angle of L1-or-L2. Yet they have not reached any consensus either, as their conclusions are apparently contradictory. Some argue that interpreters take notes mostly in their L1 (Dam, 2004) while others contend that they use their L2 more often (Szabo, 2006). Another group of researchers, though rather few in number, have proposed the possibility of using a third language in note-taking (Jones, 1998; Blaszczyk \& Hanusiak, 2010). However, most of the existing studies on language choice in note-taking are based on personal experiences and instincts, rather than empirical data. Therefore, these studies have fairly limited value in revealing the cognitive and behavioral reality of language choice in note-taking.

\section{METHODOLOGY}

This study implements both qualitative and quantitative methods, adopting questionnaires as well as experiment. The questionnaires are mainly for gathering information from the participants with regards to their experiences, knowledge and attitudes towards note-taking and translanguaging application. The experiment is carried out in three stages: (a) pretest of note-taking, (b) lecture on translanguaging, and (c) post-test of note-taking. Participants' notes taken during the pre-test and post-test are collected and analyzed to identify the pattern of changes in their language choice.

\section{A. Participants}

A total of 96 college students participated in this study. They are all third-year students majoring in English. Of all the participants, there are 13 males and 83 females with an average age of 21 . Over $90 \%$ of them are multilinguals, capable of speaking a language other than Chinese (Mandarin) and English. All participants have taken an introductory interpreting course the previous semester and acquired limited experience in note-taking. However, no formal instruction on how to take notes had been given to them yet. Furthermore, none of them has acquired any interpreting professional qualification certificate, such as CATTI (China Accreditation Test for Translators and Interpreters), and thus they are all beginner-level interpreters.

All the 96 participants completed the questionnaire, and 7 of them, who speak Chinese (Mandarin), English and Chinese (Cantonese), were chosen to participate in the note-taking experiment.

\section{B. Instrumentation}

Questionnaire: A typical five-point Likert scale questionnaire is adopted to collect information from the participants. The questionnaire is composed of three parts. The first part includes 9 statements about the past note-taking experiences of the participants; the second part includes 7 statements about their knowledge of the nature of note-taking; the third part includes 4 statements about their attitude toward future possible application of translanguaging in note-taking. Every statement is followed by five item categories, namely, "strongly agree", "agree", "neither agree nor disagree", "disagree", "strongly disagree". This survey was conducted shortly after teaching them the concept and potential benefits of translanguaging in class.

Test Materials: The selection of the pre-test and post-test materials is based on the following two considerations: (1) Clarity. The material should have a moderate delivery rate with clear articulation. (2) Practicality. Because the students are limited in their interpreting experience and ability, the materials should be appropriate both in terms of topic and of register, so as to be practical for them to follow and take notes. 
As a result, two test materials were selected, both in Chinese (Mandarin) which is their L1 (i.e., mother tongue). Test material 1 is about education in China, with 175 characters delivered in 42 seconds, and test material 2 is about shopping in China, with 177 characters delivered in 42 seconds. The difference in delivery rate is as little as $1 \%$ between test material 1 (4.17 characters/second) and test material 2 (4.21 characters/second).

\section{Data Analysis}

The questionnaire was distributed to all the 96 participants right after the lecture on translanguaging. Everyone was informed that the questionnaire is anonymous in nature, and they should complete it and turn it in within two days, which they did. The distribution and collection were carried out through wenjuanxing® which is a leading APP in the field of surveying in China.

The analysis of the feedback was performed partly through wenjuanxing®, and partly in Excel. Each item category is assigned a particular value for the sake of calculation and comparison as literature suggests:

- Strongly disagree $=1$;

- Disagree = 2;

- Neither agree nor disagree $=3$;

- Agree = 4;

- Strongly agree $=5$

The experiment was carried out in the interpreting laboratory via three stages. Before the experiment, all 7 participants were briefed on the details of the procedure and their tasks in each stage. The pre-test lasted 5 minutes, during which time they heard the test material 1 twice, took notes and finished interpreting. After their pre-test notes and audio recordings were collected, the authors gave them a 20-minute lecture on the concept and potential benefits of translanguaging in note-taking, encouraging them to fully utilize their linguistic repertoire for the best possible result. Then the 5-minute post-test was conducted with test material 2, which was also played twice. After their notes and recordings were collected, the authors announced the end of the experiment.

Each participant's recording was examined to confirm that he or she did the interpreting task in a truthful, wholehearted way. Then the authors thoroughly studied and analyzed each participant's pre-test notes and post-test notes to identify any pattern of change in language choice.

\section{FINDINGS AND DisCUSSION}

\section{A. Questionnaires}

The design, feedback and statistical analysis of the questionnaire are presented side by side in Table 1. As we have introduced in 3.4.1, each category is assigned a value of 1 to 5, with 1 being "strongly disagree" and 5 being "strongly agree". Therefore, higher average value means stronger tendency toward agreeing with the particular statement, and vice versa. Moreover, since "neither agree nor disagree" has a value of 3, we consider 3.000 to reflect the neutral attitude, with any value above this threshold corresponding to positive attitudes, and any value below corresponding to negative ones.

In Part I (Item No. 1 to 9), which is about their past note-taking experiences, there are several things to take notice of as follows:

- The average value is the highest (4.302) for Item No. 1, which means there is a strong consensus among the participants regarding the necessity to take notes while interpreting;

- In terms of language choice (Item No. 2 to 6), the only sure positive feedback is No. 6 (3.521) which shows that most participants would use both English and Chinese in note-taking, while the other items got either a negative average value (No. 3, 4 and 5) or a very weak positive one (No. 2), meaning they don't really stick to any one language, whether SL/TL or L1/L2;

- Item No. 8 received a very positive response (3.760), and Item No. 9 got a clearly negative one (2.542); from these two responses, we can infer that the reason behind their language choice is not that they are struggling to make the decision, but rather that they never seriously thought about this choice-making matter;

- Item No. 7 shows an unsurprisingly low average value of 2.448, meaning that most participants never used their L3 in note-taking. This is in line with the authors' expectation, providing that they never knew the concept of translanguaging and its benefits before.

In Part II (Item No. 10 to 16), which is about the participants' knowledge of the note-taking nature, we see a consistent positive pattern in responses (from 3.510 to 4.104). Two points are worth noticing:

- From their responses to Item No. 10 and 15, the participants appear to have a right understanding of the interpersonal variation of interpreters' notes;

- $\quad$ From their responses to the other items of this part, especially Item No. 13, the participants seem to have established a proper awareness of their linguistic repertoire as well as a positive attitude to its application, after being informed of the concept and possible benefits; their willingness to combine all languages available in note-taking is quite clear. 
TABLE 1

QUESTIONNAIRE's CONTENT, FEEDBACK, AND STATISTICS

\begin{tabular}{|c|c|c|c|c|c|c|c|c|c|}
\hline \multirow{2}{*}{$\begin{array}{l}\text { Part } \\
\text { No. }\end{array}$} & \multirow{2}{*}{$\begin{array}{l}\text { Item } \\
\text { No. }\end{array}$} & \multirow[t]{2}{*}{ Item Statement } & \multicolumn{5}{|c|}{ Feedback } & \multicolumn{2}{|c|}{ Statistics } \\
\hline & & & S.D. $(=1)$ & D. $(=2)$ & N. $(=3)$ & A. $(=4)$ & S.A. $(=5)$ & AVG. & VAR. \\
\hline \multirow{9}{*}{ ت } & 1 & $\begin{array}{c}\text { Whenever possible, I would take notes while } \\
\text { interpreting. }\end{array}$ & $1.04 \%$ & $1.04 \%$ & $4.17 \%$ & $54.17 \%$ & $39.58 \%$ & 4.302 & 0.482 \\
\hline & 2 & I always take notes in the source language. & $0 \%$ & $27.08 \%$ & $35.42 \%$ & $36.46 \%$ & $1.04 \%$ & 3.115 & 0.664 \\
\hline & 3 & I always take notes in the target language. & $3.13 \%$ & $42.71 \%$ & $43.75 \%$ & $9.38 \%$ & $1.04 \%$ & 2.625 & 0.547 \\
\hline & 4 & $\begin{array}{c}\text { I always take notes in Mandarin, regardless } \\
\text { of the source language. }\end{array}$ & $9.38 \%$ & $55.21 \%$ & $20.83 \%$ & $12.5 \%$ & $2.08 \%$ & 2.427 & 0.807 \\
\hline & 5 & $\begin{array}{l}\text { I always take notes in English, regardless of } \\
\text { the source language. }\end{array}$ & $8.33 \%$ & $66.67 \%$ & $22.92 \%$ & $1.04 \%$ & $1.04 \%$ & 2.198 & 0.409 \\
\hline & 6 & $\begin{array}{l}\text { I always take notes in a mix of Mandarin and } \\
\text { English, regardless of the source language. }\end{array}$ & $3.13 \%$ & $7.29 \%$ & $28.13 \%$ & $56.25 \%$ & $5.21 \%$ & 3.531 & 0.687 \\
\hline & 7 & $\begin{array}{l}\text { Occasionally I would use language other } \\
\text { than Mandarin and English to take notes. }\end{array}$ & $14.58 \%$ & $50 \%$ & $12.5 \%$ & $21.88 \%$ & $1.04 \%$ & 2.448 & 1.039 \\
\hline & 8 & $\begin{array}{l}\text { I never thought about which language to use } \\
\text { in note-taking but just followed my instinct. }\end{array}$ & $1.04 \%$ & $9.38 \%$ & $9.38 \%$ & $72.92 \%$ & $7.29 \%$ & 3.760 & 0.578 \\
\hline & 9 & $\begin{array}{l}\text { I often feel unsettled about which language } \\
\text { to choose in terms of note-taking. }\end{array}$ & $9.38 \%$ & $50 \%$ & $19.79 \%$ & $18.75 \%$ & $2.08 \%$ & 2.542 & 0.936 \\
\hline \multirow{7}{*}{ E } & 10 & $\begin{array}{l}\text { Notes in interpreting are something personal, } \\
\text { and it is fine if others can't read them. }\end{array}$ & $4.17 \%$ & $2.08 \%$ & $4.17 \%$ & $58.33 \%$ & $31.25 \%$ & 4.104 & 0.802 \\
\hline & 11 & $\begin{array}{l}\text { I could achieve best performance when freely } \\
\text { combining Mandarin/English in note-taking. }\end{array}$ & $1.04 \%$ & $2.08 \%$ & $13.54 \%$ & $70.83 \%$ & $12.5 \%$ & 3.917 & 0.431 \\
\hline & 12 & $\begin{array}{l}\text { It is acceptable to use language other than } \\
\text { Mandarin and English in note-taking. }\end{array}$ & $4.17 \%$ & $10.42 \%$ & $16.67 \%$ & $67.71 \%$ & $1.04 \%$ & 3.510 & 0.729 \\
\hline & 13 & $\begin{array}{l}\text { My linguistic repertoire is a composite entity } \\
\text { with various languages mixed together. }\end{array}$ & $2.08 \%$ & $13.54 \%$ & $18.75 \%$ & $59.38 \%$ & $6.25 \%$ & 3.542 & 0.769 \\
\hline & 14 & $\begin{array}{l}\text { As long as it facilitates interpreting, any } \\
\text { language is fine to adopt in note-taking. }\end{array}$ & $2.08 \%$ & $0 \%$ & $5.21 \%$ & $77.08 \%$ & $15.63 \%$ & 4.042 & 0.394 \\
\hline & 15 & $\begin{array}{l}\text { Every interpreter's notes should be unique in } \\
\text { composition and style. }\end{array}$ & $2.08 \%$ & $3.13 \%$ & $11.46 \%$ & $60.42 \%$ & $22.92 \%$ & 3.990 & 0.656 \\
\hline & 16 & $\begin{array}{l}\text { Mastering two or more languages makes me } \\
\text { more capable in note-taking. }\end{array}$ & $1.04 \%$ & $3.13 \%$ & $11.46 \%$ & $73.96 \%$ & $10.42 \%$ & 3.896 & 0.427 \\
\hline \multirow{4}{*}{$\underset{\Xi}{\Xi}$} & 17 & $\begin{array}{l}\text { In future I will choose language in note- } \\
\text { taking based on writing convenience. }\end{array}$ & $0 \%$ & $1.04 \%$ & $6.25 \%$ & $70.83 \%$ & $21.88 \%$ & 4.135 & 0.305 \\
\hline & 18 & $\begin{array}{l}\text { In future I will choose language in note- } \\
\text { taking based on reading convenience. }\end{array}$ & $1.04 \%$ & $1.04 \%$ & $8.33 \%$ & $73.96 \%$ & $15.63 \%$ & 4.021 & 0.375 \\
\hline & 19 & $\begin{array}{l}\text { In future I will consider to add more } \\
\text { languages in my existing note system. }\end{array}$ & $0 \%$ & $10.42 \%$ & $30.21 \%$ & $51.04 \%$ & $8.33 \%$ & 3.573 & 0.620 \\
\hline & 20 & $\begin{array}{l}\text { In future I will not be bothered about which } \\
\text { language to choose in note-taking. }\end{array}$ & $1.04 \%$ & $4.17 \%$ & $22.92 \%$ & $58.33 \%$ & $13.54 \%$ & 3.792 & 0.582 \\
\hline
\end{tabular}

In Part III (Item No. 17 to 20), which is about the participants' attitude toward future application of translanguaging in their note-taking, we see another consistent positive pattern in responses (from 3.573 to 4.135 ). By taking a closer look, we can see

- Item No. 17 and 18 got a very positive response, with average value being above 4.000; this shows that, overall, the participants are taking a pragmatic stance rather than a dogmatic one on future language choice in notetaking, probably under the influence of newly-learnt translanguaging concept.

- Item No. 19 received an encouraging response, with $59.37 \%$ of the participants choosing either "agree" or "strongly agree"; this demonstrates that after learning about translanguaging, most participants decide to add more languages into their existing note system to fully exploit their entire linguistic repertoire.

In brief, what we learned from the questionnaires, as seen in Table 1, is: (a) the participants generally recognize the necessity of note-taking in interpreting, but never thought about which language to choose, and thus they don't stick to any particular language but just follow their instinct; (b) they rightly understand that an interpreter's notes is personal and unique in nature, and after the lecture, they seem to have grasped the concept of translanguaging and formed a positive attitude toward it; (c) under the influence of translanguaging concept, the participants are being pragmatic rather than dogmatic about language choice in notes, and the majority of them decide to incorporate more aspects of their linguistic repertoire into their existing note system.

\section{B. Language Choice in Notes}

All the seven participants' notes are studied and counted. The contents of their notes are classified into four categories: (1) Chinese notes (any Chinese characters, both complete and incomplete); (2) English notes (any English words, both complete and incomplete); (3) L3 notes (notes in any other language besides Chinese and English); (4) Non-language notes (lines, symbols, arrows, shapes, etc.). The number and distribution of each category of notes during pre-test and post-test are shown in Table 2 and Table 3, respectively. 
TABLE 2

NUMBER AND DISTRIBUTION OF PARTICIPANTS' NOTES IN THE PRE-TEST

\begin{tabular}{|c|c|c|c|c|c|c|}
\hline & English & Chinese & L3 & Non-language & Total & E/C Ratio \\
\hline S1 & 0 & 48 & 0 & 5 & 53 & 0 \\
\hline S2 & 3 & 48 & 0 & 24 & 75 & 0.062 \\
\hline S3 & 1 & 30 & 0 & 11 & 42 & 0.033 \\
\hline S4 & 8 & 50 & 0 & 9 & 67 & 0.160 \\
\hline S5 & 1 & 44 & 0 & 11 & 56 & 0.023 \\
\hline S6 & 2 & 29 & 0 & 12 & 43 & 0.069 \\
\hline S7 & 3 & 29 & 0 & 14 & 46 & 0.103 \\
\hline
\end{tabular}

TABLE 3

Number AND Distribution OF PARTICIPANTS' NOTEs In The POST-Test

\begin{tabular}{|c|c|c|c|c|c|c|}
\hline & English & Chinese & L3 & Non-language & Total & E/C Ratio \\
\hline S1 & 1 & 48 & 0 & 8 & 57 & 0.021 \\
\hline S2 & 8 & 34 & 0 & 13 & 55 & 0.235 \\
\hline S3 & 2 & 29 & 0 & 12 & 43 & 0.069 \\
\hline S4 & 9 & 42 & 2 & 6 & 59 & 0.214 \\
\hline S5 & 12 & 13 & 0 & 14 & 39 & 0.923 \\
\hline S6 & 6 & 16 & 0 & 14 & 36 & 0.375 \\
\hline S7 & 12 & 12 & 0 & 7 & 31 & 1.000 \\
\hline
\end{tabular}

After examining the details of the data and doing the statistical calculations, we notice the following points.

- The participants generally prefer to take notes in the source language (i.e., Chinese) with only one exception (S7 in post-test). This tendency is stronger in the pre-test, and in some extreme cases, there were no notes in English at all ( $\mathrm{S} 1$ in the pre-test). The possible reason is that, as beginner-level interpreters, they are not accustomed to translate while absorbing and processing the information from the speaker. Also, in the pre-test stage, they were not aware of the benefits of exploiting their full linguistic ability yet.

- $\quad$ Although they all master a third language (e.g. Cantonese, French, Japanese, etc.), virtually none of them took any note in L3 (with S4 in post-test being the only exception), even after going through a lecture about translanguaging and its possible benefits. This is probably due to the fact that note-taking is a matter of personal habit which is hard to change in a short period of time. During the post-test, although they may have become aware of the possible benefits of applying translanguaging in note-taking, they simply lack enough drills to have their note-taking habit modified.

- After the translanguaging lecture, however, there is a considerable increase in the ratio of English notes to Chinese notes for all of the participants, especially S5 and S7. We could see this change more clearly in Fig. 1, in which blue bars show the ratios in the pre-test and orange bars show those in the post-test. In essence, every participant is making effort to take notes in a more balanced way, utilizing their both language abilities. Considering that the post-test was conducted right after the lecture, this change is clearly due to their accepting the concept and benefits of translanguaging.

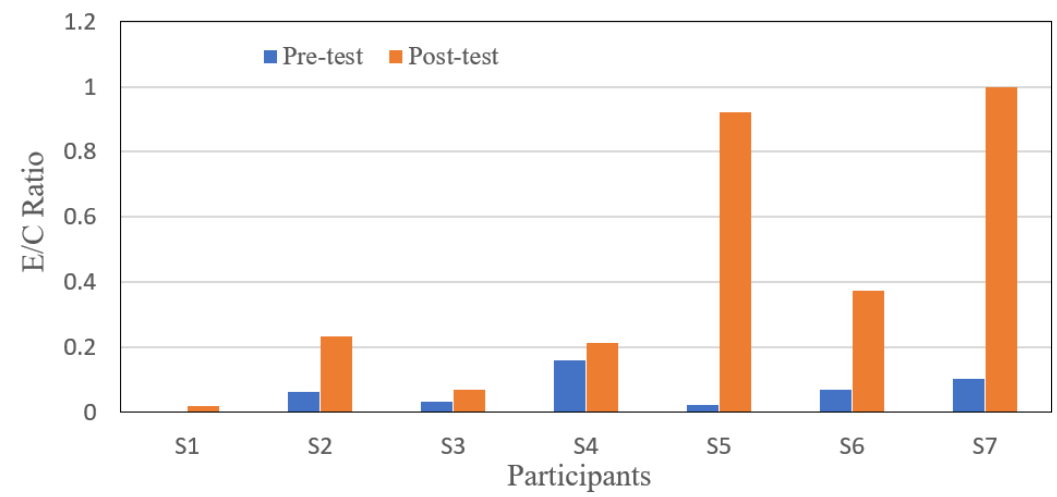

Figure 1. Participants' Notes E/C Ratio Comparison between Pre- and Post-Test

\section{CONCLUSION AND APPLICATION}

From the discussion above we can conclude that, before the lecture of translanguaging, the participants of this study in general were not clear in their mind regarding language choice in note-taking but just followed their instinct. In fact, based on the pre-test notes of the seven participants in the experiment, there is a strong and uniform tendency of using Chinese in note-taking, probably due to convenience and familiarity.

However, after being informed of the concept and benefits of translanguaging, most participants demonstrate in their questionnaire feedback a clear willingness to adopt more languages in note-taking. This is confirmed to some extent in 
the post-test of the experiment, during which period the participants' notes reflected a more balanced usage of their L1 and L2. On the other hand, hardly any notes in L3 were visibly observable during the post-test yet. This is probably because, despite the existence of willingness, one's note-taking habit needs more time and practice to change in a noticeable way.

In light of all the findings from this study, it is reasonable to conclude that teachers of interpreting courses should incorporate the concept of translanguaging and guidance on its application in the syllabus, for the students are generally open-minded about this kind of innovative theory. It is also suggested to arrange enough drills of interpreting practice, as well as timely feedback from the teacher, to help the students form the habit of applying translanguaging in their note-taking, thereby enhancing their overall interpreting performance.

\section{ACKNOWLEDGEMENTS}

This was supported in part by Zhanjiang University of Science and Technology "Consecutive Interpreting Online Open Course Project" (No.: JYJX2020021) and "First-class Online-and-Offline Blended Course of Consecutive Interpreting Project" (No.: PPJH202105YLKC).

\section{REFERENCES}

[1] Alexieva, B. (1993). On teaching note-taking in consecutive interpreting. In C. Dollerup, \& A. Lindegaard (Eds.), Teaching translation and interpreting 2: Insights, aims, visions (pp. 199-206). John Benjamins.

[2] Baker B., \& Hope A. (2019). Incorporating Translanguaging in Language Assessment: The Case of a Test for University Professors. Language Assessment Quarterly. 16(1), 408-425.

[3] Baynham M., \& Lee T.K. (2019). Translation and Translanguaging. Routledge.

[4] Blackledge, A., \& Creese, A. (2010). Multilingualism: A critical perspective. Continuum.

[5] Błaszczyk P., \& Hanusiak D. (2010). The Choice of Language for Note-Taking for Consecutive Interpreting: A Polish Perspective. MikaEL Kääntämisen ja tulkkauksen tutkimuksen symposiumin verkkojulkaisu - Electronic Proceedings of the KäTu Symposium on Translation and Interpreting Studies 4. Retrieved May 12, 2021 from https://www.sktl.fi/@Bin/40680/Blaszczyk\%26Hanusiak_MikaEL2010.pdf

[6] Burton, J., \& Rajendram, S. (2019). Translanguaging-as-Resource: University ESL Instructors' Language Orientations and Attitudes Toward Translanguaging. TESL Canada, 36(1), 21-47.

[7] Canagarajah, S. (2013). Translingual Practice: Global Englishes and cosmopolitan relations. London, UK: Routledge.

[8] Creese, A., \& Blackledge, A. (2010). Translanguaging in the bilingual classroom: A pedagogy for learning and teaching? Modern Language Journal, 94(1), 103-115.

[9] Dam, H. (2004). Interpreters' notes: On the choice of language. Interpreting, 6(1), 3-17.

[10] Garcia O. (2009). Bilingual Education in the 21st Century: A Global Perspective. Wiley-Blackwell.

[11] Garcia, O., \& Li, W. (2014). Translanguaging: Language, bilingualism and education. Palgrave Macmillan.

[12] Garcia O., Johnson S., \& Seltzer K. (2016). The Translanguaging Classroom: Leveraging Student Bilingualism for Learning. Caslon.

[13] Gile, D. (1995). Basic concepts and models for interpreter and translator training. John Benjamins.

[14] Hornberger, N.H., \& Link, H. (2012). Translanguaging and transnational literacies in multilingual classrooms: A bilingual lens. International Journal of Bilingual Education and Bilingualism, 15(3), 261-278.

[15] Ilg, G. (1988). La prise de notes en interprétation consécutive. Une orientation générale. Parallèles 9, 9-13.

[16] Jenks C., \& Lee J. (2020). Translanguaging and World Englishes. World Englishes. 39, 218-221.

[17] Jones, R. (1998). Conference Interpreting Explained. Manchester: St. Jerome.

[18] Kiramba L. (2017). Translanguaging in the Writing of Emergent Multilinguals. International Multilingual Research Journal. $11(2), 115-130$.

[19] Kwon H., \& Schallert D. (2016). Understanding translanguaging practices through a biliteracy continua framework: Adult biliterates reading academic texts in their two languages. Bilingual Research Journal, 39(2), 138-151.

[20] Lewis G., Jones B., Baker C. (2012). Translanguaging: Origins and development from school to street and beyond. Educational Research and Evaluation, 18(7): 641-654.

[21] Li, W. (2011). Moment analysis and translanguaging space: Discursive construction of identities by multilingual Chinese youth in Britain. Journal of Pragmatics, 43(5), 1222-1235.

[22] Li, W. (2017). Translanguaging as a practical theory of language. Applied Linguistics, 39(1), 9-30.

[23] Mikkelson, H. (1983). Consecutive interpretation. The Reflector, 6, 5-9.

[24] Otheguy, R., Garcia, O., \& Reid, W. (2015). Clarifying translanguaging and deconstructing named languages: a perspective from linguistics. Applied Linguistics Review, 6(3), 281-307.

[25] Pennycook, A. (2018). Posthumanist applied linguistics. Routledge.

[26] Pontier R., \& Gort M. (2016). Coordinated Translanguaging Pedagogy as Distributed Cognition: A Case Study of Two Dual Language Bilingual Education Preschool Coteachers' Languaging Practices During Shared Book Readings. International Multilingual Research Journal. 10(2), 89-106.

[27] Rozan, J. (2002). Note-taking in Consecutive Interpreting. In A Gillies, \& B. Waliczec (Eds.). Language and Communication 3. Tertium Society for the Promotion of Language Studies. Retrieved July 6, 2021 from http://www.someya-net.com/01Tsuyaku/Reading/Rozan.pdf

[28] Seleskovitch, D. (1975). Language, langues et mémoire. Étude de la prise de notes en DEST interprétation consécutive. Minard Lettres Modernes.

[29] Seleskovitch, D., \& Lederer, M. (1989). Pédagogie raisonnée de l'interprétation. Didier Erudition. 
[30] Szabo, C. (2006). Language choice in note-taking for consecutive interpreting: A topic revisited. Interpreting, 8(2), 129-147.

[31] Turnbull B. (2019). Translanguaging in the planning of academic and creative writing: A case of adult Japanese EFL learners. Bilingual Research Journal. 42(2), 232-251.

[32] Xiao, X. (2002). Interpreting Research in the West: a Critical Analysis of Its History and Current Status. Journal of Foreign Languages. 14(4), 71-76.

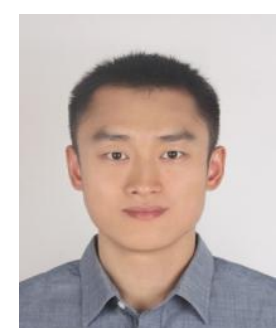

Zhiliang Yue received his Bachelor of Science in Biological Sciences from Fudan University, Shanghai, China, in 2008, and his Master of Science in Petroleum Engineering from University of Southern California, Los Angeles, United States, in 2014. At present, he is a $\mathrm{PhD}$ candidate of the Language and Global Communication Program from Srinakharinwirot University, Bangkok, Thailand. After his early years of engineering career in multinational companies, he has been dedicated to English teaching and research in Zhanjiang University of Science and Technology since 2016.

Mr. Yue currently works as a lecturer at the School of Foreign Studies, Zhanjiang University of Science and Technology, China. He is the person in charge of several university-level projects related to interpreting teaching and research, including the ones cited in this paper. He is a certified translator/interpreter, holding certificates of CATTI English Interpreting Level 2 and CATTI English Translation Level 2. His research interest and publications include interpreting studies and second language acquisition.

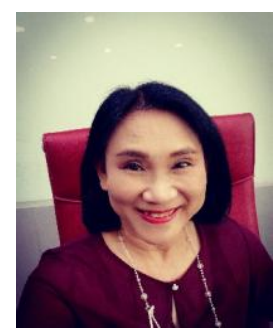

Anchalee Jansem received her Bachelor of Education (cum laude) in English Education from Srinakharinwirot University Bangsaen, Thailand, in 1987; her Master of Education Studies in TESOL from University of South Australia, Adelaide, Australia, in 1997; and her Doctor of Education in Curriculum and Instruction with a concentration in TESOL from Illinois State University, USA, in 2008. Her career directly involves teaching both undergraduate and graduate courses in instructional methodology, curriculum and instruction, and professional development for language teachers.

Dr. Jansem currently serves as Dean of Faculty of Humanities at Srinakharinwirot University, Bangkok, Thailand. Previously, besides her teaching, she was Associate Dean for Academic Affairs and International Relations at Faculty of Humanities as well as Acting Director of International Relations and Organizational Communications of the university. Her research interests and publications include second and foreign language education, language teacher professionalism, and teacher talk. 